\title{
Process Model for Enterprise Application Integration: Case for a Customs Department
}

\author{
Christopher A. Moturi \\ School of Computing and \\ Informatics \\ University of Nairobi \\ Nairobi, Kenya
}

\author{
Gabriel Githehu Kinu \\ School of Computing and \\ Informatics \\ University of Nairobi \\ Nairobi, Kenya
}

\author{
Andrew Mwaura Kahonge \\ School of Computing and \\ Informatics \\ University of Nairobi \\ Nairobi, Kenya
}

\begin{abstract}
This paper develops a case for a process model for addressing the challenges of Enterprise Application Integration in a Customs Department. Different methodologies that may be employed for integrating disparate business applications were evaluated and a checklist of factors to consider in identifying the most suitable in different situations was suggested. Based on this review and responses obtained from selected IT professionals, a process model for application integration was constructed and validated through expert reviews to determine its applicability. The results obtained demonstrate the model appears credible and comprehensive enough to handle most of the likely emergent issues.
\end{abstract}

\section{General Terms}

Enterprise Application Integration (EAI), Customs Department

\section{Keywords}

Enterprise Application Integration Model, Enterprise Application Integration Adoption

\section{INTRODUCTION}

As business enterprises develop independent information systems, it is realized that the disparate applications, dealing with distinct business domains, cannot communicate with each other. A number of problems often arise in such case, including duplication of datasets, integrity of data, and inconsistency of reports generated. Re-developing these applications as one way to solve these problems may not be prudent. It is better to find ways of using existing databases and applications rather than recreating the same business processes and data repositories. There is therefore need to find ways of integrating disparate applications into a unified set of business processes. In addition, internal applications need to share data with external applications belonging to organizations with which it is important to share some business data. These challenges have led to the emergence of Enterprise Application Integration (EAI), the unrestricted sharing of data and business processes among any connected applications or data sources.

The motivation behind this research was to develop a structured way of address the challenges of EAI that have been experienced at the Customs Department in Kenya, after it was realized that the existing system development methodologies had certain weaknesses that made them inadequate for application integration projects. The study sought to evaluate different methodologies that may be employed for integrating disparate business applications and suggest a checklist of factors to consider in identifying the most suitable in a Customs Department. An analysis and design process model for application integration projects was proposed and evaluated to determine its applicability.

A number of methodologies were identified but were found wanting in that most are generic and only provide very highlevel recommendations on how to go about undertaking integration projects. They seem to ignore the fact that integration projects are very unique and are best tailored to organization-specific situations. Most have a weak productperspective by only describing a general step-wise process and ignoring specific deliverables expected at each step. A situational process model that can be used to undertake application integration projects within and across enterprises such as cooperating Government agencies was proposed.

\section{THEORETICAL BACKGROUND AND LITERATURE REVIEWED}

\subsection{Key Concepts}

According to EAI Industry Consortium (2004), Enterprise Application Integration (EAI) is the process of integrating multiple applications that were independently developed, may use incompatible technology, and remain independently managed. These applications can reside within a company's enterprise boundaries or across multiple company boundaries connected over the Internet. Integration may therefore be looked at from two perspectives: Application-to-Application Integration (A2A) which is the integration of applications and business processes within the same enterprise; Business-toBusiness (B2B) which is the integration of a business enterprise's applications and business processes with external business systems operated by trading partners, customers or suppliers. Process models represent a networked sequence of activities, objects, transformations, and events that embody strategies for accomplishing a given goal (Scacchi, 2001). (Rolland, 1998) identifies three main aims of process models: Descriptive - to record trace of what actually happens during a process; Prescriptive - to define desired processes and how they should be performed; Explanatory - to provide the rationale of processes. A method is an approach to perform a systems development project, based on a specific way of thinking, consisting of directions and rules, structured in a systematic way in development activities with corresponding development products (Brinkkemper, 1996). Method engineering is the engineering discipline to design, construct 
and adapt methods, techniques and tools for the development of information systems (Brinkkemper, 1996). Situational method engineering is a method engineering technique that facilitates the construction of methods to address unique requirements. Business Process Modeling Notation (BPMN) is a method of illustrating business processes in the form of a diagram similar to a flowchart. In this paper, BPMN is used to illustrate the business process flows for both the current business processes (AS-IS) and proposed business processes (TO-BE). (Linthicum, 2000) identifies four main levels at which integration can be performed in an enterprise application: Data (suited for systems where the applications are decoupled from their databases); Application Interface (most applicable for ERP applications); Business Method (sharing of business logic among different applications): and User Interface (a non-invasive common point of integration by using screen scraping and content aggregation).

\subsection{Selecting the Right Integration Solution}

In order to help organizations chose the right EAI solution, (Bosch, 2010) suggests a selection-method with the following activities: determine the enterprise problem-domain; describe process structure; describe application interfaces and it infrastructure; mapping; analyze integration 'gaps'; restructuring activities; identify restrictions and conditions; define requirements; and select solution.

However, when it comes to the actual integration technology, there are three broad factors that should be considered (TechTarget, 2009): a) Features of Applications - Packaged applications from different vendors sometimes come with standard adapters that can be used. If your applications are homegrown, heavily customized, or legacy mainframe systems, then integration will likely require building an adapter from scratch. b) Types of Transactions -If the applications to integrate support long-running transactions, then a message-queuing solution that can send messages to a queue and then forward them to the destination application may be the preferred choice; If the applications support shortlived transactions, where the client application sends a request to the server applications and waits for a response, then a Remote Procedure Call (RPC)-based solution may be preferred. c) Type of Data - Differences in the data formats and object models of different data bases may necessitate technologies that provide some kind of transformation technology to interpret data from different systems. Other factors identified by (Linthicum, 2000) will include size and complexity of transactions, data transformation requirement, operating environments of the communicating systems, and data latency.

\subsection{A Review of Existing EAI Methodologies}

\subsubsection{The Total Business Integration Methodology}

The Total Business Integration (TBI) (EAI Industry Consortium, 2004) is designed for projects that are integrating data, applications and processes within or across multiple business units using heterogeneous systems, throughout the enterprise. It suggests a 4-step approach to integration as follows: a) Define - This phase is to identify the scope, goals, and objectives of the project; perform detailed business process analysis; identify technical requirements; and plan for the software quality assurance activities.

b) Design - Develop the logical design; select data format and exchange standard; perform data mappings; define the schema; and develop architecture recommendation.

c) Build - Develop the integration services; complete the technical documentation; and execute test cases.

d) Deploy - Make sure that the integrations meet the desired requirements that were outlined in the define phase through quality assurance/user acceptance testing and deploy the integrations in a production environment once the integrations have met the quality standards.

This methodology is based on a set of inputs and deliverables for each of the four methodology phases. Outputs from earlier phases are part of the inputs in subsequent phases. The methodology recommends a set of templates that can be used for specific tasks in each of the phases. This is essentially a top-down approach, driven by business process analysis with the desired outcome to address the integration of entire business processes, and not simply individual applications or data sources. However, the methodology can also be used in a bottom-up approach where projects can select and use templates from the methodology that meet their requirements.

\subsubsection{2-Step EAI Program}

Linthicum (2000) suggests a high-level process 12-step methodology which can be summarized as follows:

a) Understanding the Enterprise and Problem Domain: This is about understanding the problem domain in the context of the organization including structure and content of the various information systems, as well as the business requirements of each organization.

b) Making Sense of the Data: Identifying the data, data cataloguing, and building the enterprise metadata.

c) Making Sense of the Processes: Understand and document all business processes and how they relate to each other and to the enterprise metadata model.

d) Identifying any Application Interfaces: Identification of the available application interfaces in support of application interface-level EAI and suggests that the starting point should be creation of an application interface directory.

e) Identifying the Business Events: Identification of all relevant business events that occur within an enterprise together with all resulting reactions to the events.

f) Identifying the Data Transformation: This is about how schema and content of the data moving between systems will be transformed so that is understood across systems.

g) Mapping Information Movement: The purpose is to create an understanding of the movement of information from data stores, across processes, systems and interfaces.

h) Applying Technology: Selecting the proper enabling technology. 
i) Testing, Testing, Testing: This step is about testing of the EAI solution and hence emphasizes the importance of creating adequate test plans.

j) Considering Performance: Emphasis here is on designing for performance and by testing performance before going live.

k) Defining the Value: Determining the business value of integrating systems.

1) Creating Maintenance Procedures: Determining how the EAI solution will be maintained over time.

\subsubsection{Development of Integrated IT Infrastructures}

This 8-stage methodology for the development of integrated IT infrastructures was proposed by (Themistocleous \& Irani, 2006) out of the acknowledgement that, although the traditional system development methodologies have contributed immensely toward construction of organizations' IT, they lacked focus on the emerging area of EAI. The stages are as follows:

1. Planning: This stage involves laying the ground work for the proposed project and should include a feasibility study that should consider at least 10 factors namely costs, benefits, barriers internal pressures, external pressures, support, IT infrastructure, IT sophistication, evaluation framework for the assessment of integration technologies, and evaluation framework for the assessment of EAI packages.

2. Scenarios Building and Evaluation: Building multiple integration scenarios and testing them using simulation tools.

3. Business Process Reengineering: Based on these scenarios built in stage 2, there may be need to change some processes to run the business the way the organization would desire and not on the way that some software packages dictate.

4. Systems Restructuring: This may necessitate phasing out some systems to remove problems such as data redundancy, performance bottlenecks.

5. Requirements Analysis: Having built and evaluated scenarios, BPR, and gone through system restructuring, there is now a better view regarding the gaps in the IT infrastructure and the new applications that are required to fill these gaps or replace legacy systems.

6. Filling the Gap - New Systems Development: This stage deals with the analysis and the development of those applications that are required to complete the IT infrastructure.

7. Integration and Testing: The actual integration of the IT infrastructure should start once the applications are on place.

8. Operation and Maintenance: Operation and the maintenance of the integrated IT infrastructure.

\subsection{Key Related Literature}

Erasala et al (2003) developed a case for EAI in electronic commerce by discussing various ways in which EAI can be realized and illustrated how organizations can improve gains by implementing the appropriate EAI solution. They concluded on the need to combine the decision-making capabilities of participation of partners in order to monitor all the elements of an organization in order to enable the integration of inter-enterprise decisions. Further, they give a bright outlook for the future growth of EAI to accommodate new business needs but organizations need to choose technologies that add value, delivered individually, and in harmony with other technologies.

Irani et al (2003) have discussed the need for a better understanding of EAI and its impact on information system lifecycle and have proposed a classification framework that categorizes the types of applications that can be integrated with existing technologies. This EAI classification is a suitable tool for managers in evaluating and implementing ERP technology within and between customers/suppliers in their supply chain.

In their paper (Chen and Wong, 2004) argued that the adoption of EAI is the consequence of a clear identification of the strategic positioning of an organization, the understanding of existing inhibitors and the awareness of the benefits of a chosen technology.

Oba and Komoda (2001) proposed a business process-based method for the implementation of EAI using workflow techniques that divides enterprise information system into business processes and work logic that comprises the system. Their workflow model uses a CORBA interface to integrate different types of systems, and state transition model based on databases to dynamically control processes. This allows organizations to define their business processes and rules so that the business processes can flexibly adapt to changes in the organization and its applications.

Surugiu (2012) defines a solution for EAI on three levels i.e. software product development methodology, technical implementation, and functional analysis. The paper stresses the context of these approaches, methods of optimization of business processes through an integrated approach, options for achieving a fully integrated information system respecting the principle of maximizing efficiency.

Xin (2009) discusses traditional EAI techniques and the challenges and advantages for application integration with Web Services technology. They propose a model for EAI with Web Services that would efficiently implement the integration of diverse applications and systems within or between the enterprises. The model aims to provide a solution with a broad support for services integration beyond applications integration.

A comparison of frameworks that can be used to model EAI with other widely accepted frameworks has been made by (Losavio et al, 2005) by surveying common enterprise system modeling frameworks. They have defined a set of reusable features that can be used to identify the main weakness and strength of these frameworks. The strong points include the introduction of the different integration views for each integration levels, and standard UML specification used. The weak points include lack of human aspects whereby the participation of the stakeholders is fundamental for achieving the desired project goals.

Sharif et al (2005) have analyzed failures of integrating Enterprise Resource Planning (ERP) systems with legacy 
processes using EAI approach and have presented a model for post-hoc evaluation that seeks to provide insights to the failed approach to ERP integration. The authors highlight the importance of placing the success or failure of enterprise implementations in terms $\mathrm{o} * \mathrm{f}$ an overall information systems evaluation approach. The critical aspects of ERP and EAI implementation that define success and failure have been identifies as follows: clarification of business goals and objectives; management support; effective business process reengineering; systems integration ability; effective interdepartmental collaboration and communication; adherence to an integration lifecycle approach; and effective enterprise information systems modeling.

Adoption of EAI in industry has benefits as well as barriers such as those identified by Mantzana and Themistocleous (2006) in the healthcare industry. They further identified and mapped actors to these benefits and barriers. Their proposed approach improves the realization of EAI adoption benefits and barriers, enhances the analysis of EAI adoption by incorporating an actor-oriented approach, and facilitates decision-makers in realizing EAI adoption.

Kamal and Themistocleous (2009) explored the adoption life cycle stages and identified factors that influence the decision making process for EAI adoption in local government authorities. Using case study approach the finding indicate most of the factors identified influence the decision making process for EAI adoption on each phase of the adoption lifecycle.

\section{METHODOLOGY}

\subsection{Research Design}

Based on the review of existing methodologies through literature review and responses from IT professionals in technical fact finding stage, an EAI process model was constructed. Three methodologies were selected as described in 2.3: Total Business Integration Methodology, the 12-Step EAI Program, and the Development of Integrated IT Infrastructures. Each of these methodologies was evaluated for coverage of one or more of the requirements outlined in Table 1. Each was represented in a process-data diagram that combines activities in the method with the deliverables thereof. Method fragments for each of the methodologies were extracted into a matrix. Each of the fragments was then evaluated for coverage of the whole or a given aspect of each of the nine process model requirements.

The construction of the process model applied the Fragments Assembly Technique of Situational Method Engineering proposed by (Weerd, 2005) and (Ralyté \& Rolland, 2001) to assemble fragments from existing related methodologies or 'method chunks' based on the needs of the current situation. The approach adopted the following four steps: Analyze implementation situations and identify needs or requirements for new method; Select candidate methods that meet one or more aspects of the identified needs; Analyze candidate methods and store relevant method fragments in a method base; and Assemble a new method from useful method fragments and use route map configuration to obtain situational methods.

The requirements for the proposed process model were selected from responses to questionnaires to domain users and technology experts as well as (Bosch, 2010) and (Weerd, 2005) and are listed in Table 1.

Table 1: Requirements for the Proposed EAI Process Model

\begin{tabular}{|l|l|}
\hline ID & Requirement Description \\
\hline R01 & $\begin{array}{l}\text { The method should allow understanding the } \\
\text { organizational context including information about } \\
\text { the organizations participating in the integration } \\
\text { initiative as well as the systems }\end{array}$ \\
\hline R02 & $\begin{array}{l}\text { The method should assist in defining requirements } \\
\text { for the application-integration solution }\end{array}$ \\
\hline R03 & $\begin{array}{l}\text { The method should allow representation of the } \\
\text { current business processes 'AS-IS' }\end{array}$ \\
\hline R04 & $\begin{array}{l}\text { The method should allow for identification of data } \\
\text { exchange points }\end{array}$ \\
\hline R05 & $\begin{array}{l}\text { The method should allow definition of the } \\
\text { characteristics of the data exchange points in the } \\
\text { current business processes ('AS-IS') }\end{array}$ \\
\hline R06 & $\begin{array}{l}\text { The method should provide for redesigning } \\
\text { business processes where necessary to take care of } \\
\text { the weaknesses in the 'AS-IS' processes and } \\
\text { represent same in proposed business processes } \\
\text { 'TO-BE' }\end{array}$ \\
\hline R07 & $\begin{array}{l}\text { The method should allow representation of the data } \\
\text { exchange points in the 'AS-IS' and 'TO-BE' } \\
\text { business processes and integration points in the } \\
\text { 'TO-BE' } \\
\text { point based on integration point-specific } \\
\text { characteristics } \\
\text { technology/solution to use for a given integration } \\
\text { The method should allow selection of an } \\
\text { application-integration solution for each integration } \\
\text { coint, based on integration point-specific } \\
\text { characteristics }\end{array}$ \\
\hline
\end{tabular}

It can be summarized that the Total Business Integration Methodology met the following requirements: R01, R02, R03, R04, R05, R08; R09; the 12-Step EAI Program met R01, R03, R04, R05, R06, R07, R08; and the Development of Integrated IT Infrastructures met R02, R03, R06, R08. After the analysis of candidate method fragments, a process model was constructed as shown in Figure 1. This was done iteratively, with the participation of selected respondents.

\subsection{Data Source}

The study area was Custom Department of the Kenya Revenue Authority. The selected business processes are concerned with facilitation of clearance of imported cargo and generally cover manifest management and import declaration of both sea and air cargo. The selection was advised by the need to identify a business domain that could reasonably be used to demonstrate use of the proposed application integration model for application integration initiatives. The key issues considered were: a domain where there is a lot of 
interaction with external organizations; a domain where there are numerous internal applications developed using different technologies and operating on different platforms; and a domain where there is a lot of exchanges of data among both internal and external business entities, either manual or automated.

\subsection{Data Collection and Analysis}

The key method of data collection used was questionnaires, with different questionnaires used at each of the stages due to the different target groups and purpose of the study in the different stages.

\subsubsection{Business Users}

In the initial fact finding a web-based wizard-like contextsensitive questionnaire was used because the respondents came from different areas of specialization and therefore only certain questions would be relevant to them. The key questions in the questionnaire were: the business application used; duplication of function; duplication of data; reasons for application-to-application communication; any attempt before to achieve application-to-application communication; reasons for lack of integration initiatives; challenges faced as integrating applications; applications that should exchange data; integration technologies that have been applied.

When selecting the potential respondents, the following considerations were taken into account: the need to have the right mix of business domain and technical knowledge selected from the continuum of specializations available in the study area; and the need to ensure that the views of respondents outside the study area are also solicited.

The questionnaire was distributed to 100 respondents, 50 being randomly selected while 50 were targeted. In the latter group each individual was deliberately picked based on their perceived experience in the business domain or application integration issues in the domain. Of this group, 25 were IT specialists with limited to advanced business knowledge while 25 were business users with limited to moderate IT knowledge. 78 responded to the questionnaires and their responses are summarized below.

$64 \%$ felt there are tasks that are duplicated across applications including capture of PIN, capture of employee information in the customs application name SIMBA. $64 \%$ felt employee data in SIMBA application is duplicated.

$83 \%$ responded identified the following challenges: errors in data received; too much effort spent redoing tasks to produce data that already exists in other systems; delays at the national port.

On perceived lack of integration initiatives, $65 \%$ selected lack of appreciation of integration; $56 \%$ selected lack of technical skills; $86 \%$ disinterest by management; while $78 \%$ vested interests.

On why integration failed, out of the $89 \%$ who responded, the following were identified as the main reasons: disinterest by management; vested interests; disinterest by partner organizations; funding problems; no real champion; unclear requirements by users; unrealistic requirements that could not be achieved with available data; infrastructural problems; lack of skills.
On why integration initiative succeeded out of $66 \%$ who responded the following were identified: management support; only a simple solution was required; it was being driven from the very top; there was funding.

On problems faced as a result of the integrated applications out of the $67 \%$ who responded the following were identified: constantly changing data requirements; poor support by solution provider; infrastructural problems; one point of failure; blame game among participating organizations; security concerns.

Out of the $63 \%$ response the integration technologies they were aware of are VAN (Value Added Networks); Web services; and EDI over FTP.

Out of $63 \%$ who responded the following came out as the considerations for technology used: how crucial is data consistency among different data sources for this message; message expiry; operating environments of both the sending and receiving applications; and message format constraints.

Out of $100 \%$ respondents, the following were identified as the reasons for inability to meet stakeholders' needs: port complaints take too long; shipping agents approvals for amendments take too long; port manifest has inconsistencies with KRA manifest.

Out of $100 \%$ respondents the following application were identified for data exchange: SIMBA with Port: releases should be automatically exchanged due to need for faster processing and to avoid errors; need for a single manifest to go to Port and Manufacturers after approval by customs; port targeting memos take too long and sometime are not sent so there is need to improve the process; amendments should be paid for using CCRS like all other KRA payments SIMBA with Port Ground Handlers: Releases should be automatically exchanged due to need for faster processing and to avoid errors.

\subsubsection{IT Experts}

In the technical fact finding stage, the key interaction group comprised of IT professionals with advanced experience in systems lifecycle, available methodologies and, wherever possible, experience in application integration projects. The key questions in the questionnaire designed for this group covered: involvement in an integration project; methodology used for analyzing requirements; awareness of any methodology specifically for integration projects; characteristics to look for in the methodology for a system integration project; application integration technologies applied in the organization; and considerations in the choice of particular integration technology. This questionnaire was sent to 15 IT professionals; and 12 responses were received. The responses were evaluated and similar ones grouped together as summarized below.

A fusion of the old waterfall model; prototyping; Rapid Application Development (RAD) methodologies were used for analyzing requirement and designing. The challenges faced integration projects include users unable to bring out exactly what they want; variations in technologies between systems being integrated; resistance from users due to existing cultures; scope creep due to changes in requirements; unrealistic timelines; communication gaps; interference from vested interests; too much focus on the coding and less focus 
on non-functional requirements; and incomplete requirements due to speed of delivery.

None of the IT expert was aware of any methodologies specifically meant for systems integration undertaking. The characteristics to look for in a system integration project methodology include: metrics for measuring the success of integration projects; exhaustive requirements collections; ability to identify clearly what is moving from one point to the other including format, urgency and other metrics; allowing for change of existing systems to accommodate any required change.

On desirable characteristics to look for in a systems integration project methodology the following were identified: collaboration with stakeholders \& developers; implementing functionality based on priority; proper testing; technology independent; well documented, easy to comprehend and use; guide integration process in a cost effective manner; clearly definition of stakeholders involved; modularity; feedback provision at every stage/iteration; harmonization of data formats; proper identification of information exchange points and characteristics.

The application integration technologies that have been applied in the organization were identified as RPC and Web services; direct database connections; file transfer via Value Added Networks. The considerations on the choice of particular integration technology were identified as security; reliability; scalability; synchronization requirements; operation standards e.g. XML, EDI, IATA.

\section{RESULTS AND DISCUSSION}

\subsection{The Proposed Enterprise Application Integration Process Model}

The model proposed is a 5-step process model, the key steps being: Business Area Analysis; Business Process Analysis; Business Process Redesign; Design; Build. The following sections describe this process in more details. The Process Flow Diagrams for the model is shown in Figure 1.

\subsubsection{Step 1: Business Area Analysis}

The aim of this step is to create an adequate understanding of the business domain envisaged to be within the scope of the integration project. It should involve review of the organizational entities, users and applications expected to be within the scope. Three key activities must be performed.

i. Organizational Analysis: Analysis of all organizations participating in the integration initiative. This should also include affected departments in the participating organizations where it is deemed that the role of the said departments is important enough to be of interest in the integration project. Some of the key details expected to be captured can be found in the organization analysis template in Section A1.1 of Appendix 1.

ii. Stakeholder Analysis: This involves identifying individuals, groups or organizations expected to affect or be affected by any activities or deliverables of the integration project. This information is used to assess how the interests of those stakeholders should be addressed. The stakeholder analysis template in Section A1.2 of Appendix 1 provides more details. iii. Applications Analysis: An application is any business software designed to help any of the organization entities within the project scope to perform specific tasks that may be affected by the integration projects. Such applications may also either be sources of data for other applications, destinations for data from other applications or may be subject of any changes or restructuring that may become necessary as a consequence of the project. This activity aims at capturing key details of such applications such as operating environment, implementation technologies and application interfaces. The details may be captured in the organization analysis template in Section A1.1 of Appendix 1.

\subsubsection{Step 2: Business Process Analysis}

In this activity, the processes that are inside the scope of the integration project are identified and documented. It should involve the following tasks:

i. Identify the Business Processes: The business processes that are in the integration project scope. General details of the processes such as description and process owners should be provided. Process boundaries that mark the entry points of the process inputs and the exit points of the process outputs should be defined. The details can be captured using the process analysis template in Section A1.3 of Appendix 1.

ii. Identify Message Flows: This should involve simply identifying documents (electronic or paper) flowing within or across processes and organization boundaries. The message description template in Section A1.4 of Appendix 1 may be used for this purpose.

iii. Construct Current Process Flow (AS-IS): Construct a process flow diagram representing the current status that illustrates the various processes and their interrelationships and that clearly delineates process, functional area and organizational boundaries. Message flows that are of essence in the integration exercise should be marked.

iv. Create Message Descriptions: This should be a textual description, preferably in tabular form, of the message flows identified in (ii) above and represented in process flow described in (iii). The message description template in Section A1.4 of Appendix 1 is recommended for this purpose.

v. Create Process Descriptions: This should be a textual description, preferable in tabular form, of the processes identified in (i) above and represented in process flow described in (iii). The details can be captured using the process analysis template in Section A1.3 of Appendix 1.

vi. Identify Weaknesses in Current Processes: Any weaknesses in the identified processes are documented. This is an important step as it forms the basis for any subsequent work that may be needed in Step 3: Business Process Redesign. The process analysis template in Section A1.3 of Appendix 1 may be used for this purpose. 


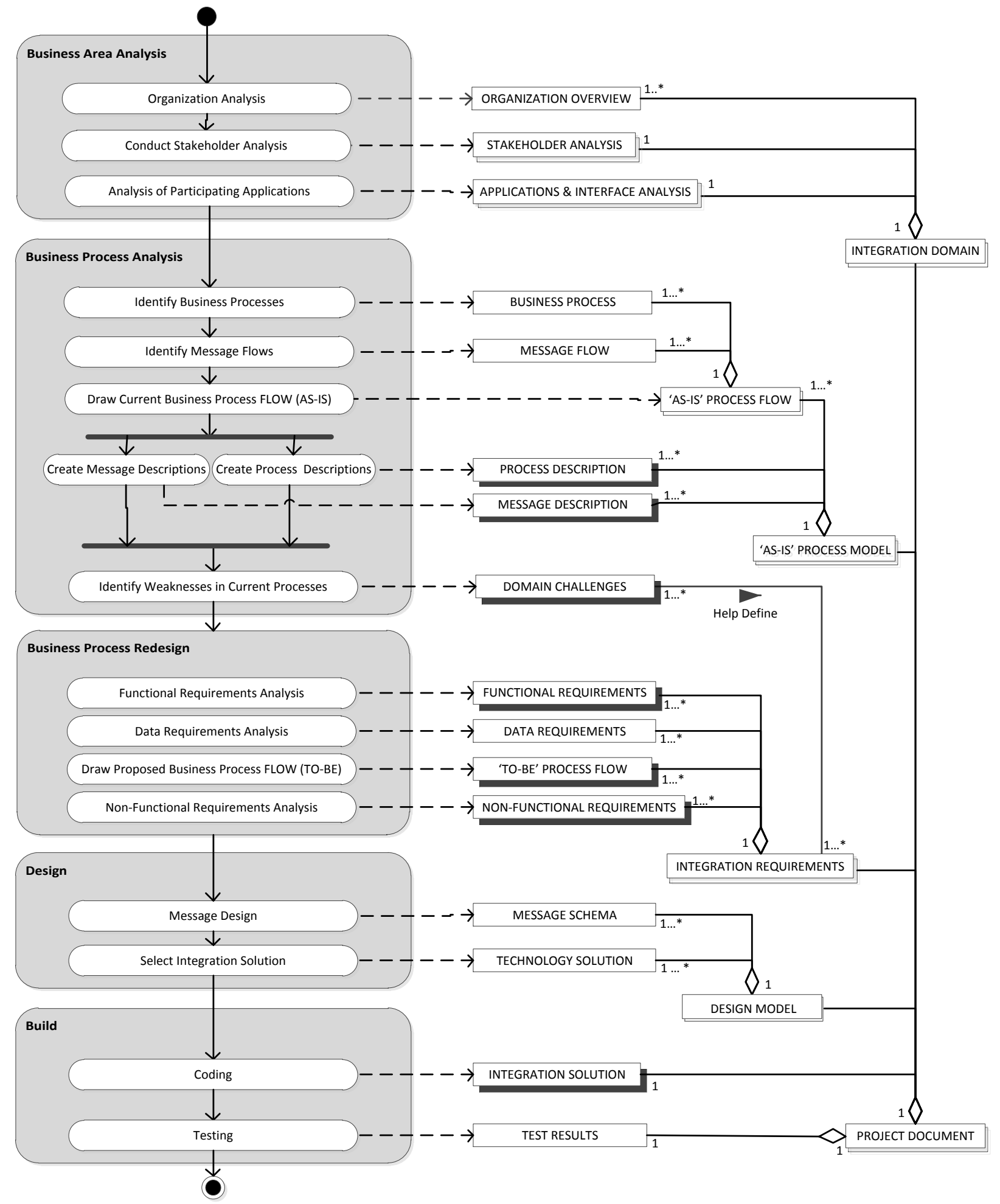

Figure 1: Proposed Process-Data Diagram 


\subsubsection{Step 3: Business Process Redesign}

It may be necessary to introduce a variation of the way things are done in one or more of the business processes so as to accommodate a necessary requirement for transformation into an integrated environment. This is the purpose of this step. The sub-activities in this step need not be carried out in any sequence. In fact it is recommended that is should be iterative because of the complex inter-relationships among the products of the sub-activities. The key tasks are:

i. Function-al Requirements Analysis: This should involve analysis of all proposed data exchange points in order to determine the needs or conditions to meet for each integration point.

ii. Data Requirements Analysis: The application owners identify the data fields required to support the business process flow in the source and target systems.

iii. Construct Proposed Process Flow (TO-BE): Construct a process flow diagram for the proposed processes.

iv. Non-Functional Requirements Analysis: This activity involves identification of requirements in support of the integration functionality. It should include aspects such as performance, error handling and monitoring requirements for business transactions and interfaces.

\subsubsection{Step 4: Design}

The purpose of this step the creation of models on which the construction the integration solution and necessary amendments to existing systems will be based.

i. Message Design: This activity defines the data passed between systems, format of the data, and how that data must be transformed between one processes to another. Wherever possible, it should also involve designing test cases to be used for unit, integration and system testing to verify interface functionality. The following steps may be followed.

- For each message, define the message structure including data element content, data type, data element format as well as indication of the optionality or otherwise of each data element. A data element is the smallest unit of meaningful data that cannot be divided any further. A data structure is a collection of related data element. The template in A1.5 of Appendix 1 may be used

- For each message, define the message characteristic including timing, frequency, size indications, latency etc.

- Select the format of the message (e.g. XML, EDIFACT etc). Define the message schema if the message format selected can be enforced using schemas.

ii. Select Integration Solution: Many possible integration technologies exist that can be used to implement integration solutions under varying situations as differentiated by identifiable characteristics of specific data exchange/integration points. Various factors therefore have to be considered when selecting the technology to use in a given case. A suggested checklist of factors to guide designers in the choice of integration technology is provided in Appendix 2.

\subsubsection{Step 5: Build}

i. $\quad$ Coding: The software codes necessary to actualize any changes to affected systems and for the integration are developed. ii. Testing: This is a full regression test on all affected applications as well as integration tests on all interfaces.

The expected deliverables of the process model are represented using a Product Breakdown Structure in Figure 2.

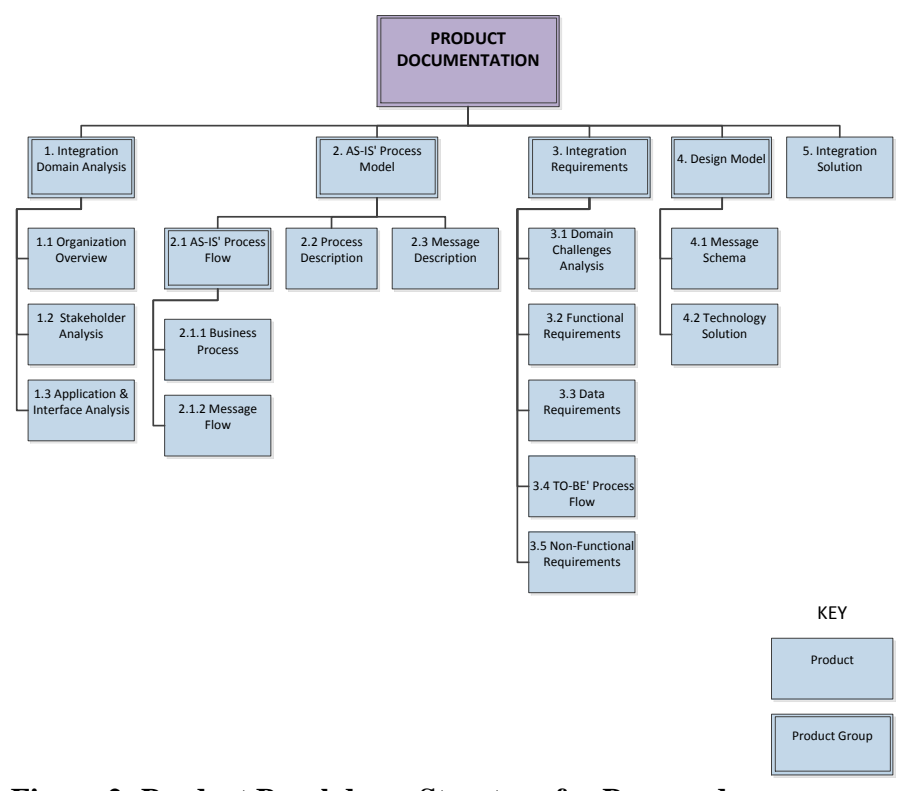

Figure 2: Product Breakdown Structure for Proposed Process Model

\subsection{Model Validation}

Method validation is an important part of Method Engineering and serves the purpose of confirming that a process-model is suitable for its intended use. Two approaches to our model validation were used: Expert Validation (by obtaining the views of domain and technology experts); Business Scenario Validation (by subjecting the model to a real-life situation and evaluating the results at each stage).

\subsubsection{Expert Validation}

The proposed model, project rationale, and the project deliverables created were sent to 5 experts from different countries: Consultant \& Expert in System Integration also Member of the UN/CEFACT Working Group on Customs and Single Window (Canada); Business Analyst \& University Lecturer (Kenya); Consultant \& Certified Business Analysis Professional (India); Consultant for Single Window, Customs and Port System Integration (Mauritius); and University IT Lecturer (Kenya). The key questions during this validation and their overall responses are summarized below.

On if the approach used to construct the proposed EAI process model was suitable and/or the aspects of the approach that needed improvement, the experts confirmed the method was suitable and well informed since it is based on the aggregation of the components of other methodologies that are not an exact fit to the situation at hand. A strong point for the use of this approach is the selection and evaluation of the candidate reference methodologies. The approach has a strong theoretical basis, and suggestions to improve or modify it should be based of detailed study.

The suggested improvement were to borrows from previous works and builds on them. The weakness will be if there are no reliable methodologies in existence to borrow from. The process model describes about process analysis but quickly 
jumps into system details when describing messages. There seems to be a "systems analysis" bit missing. An As-Is and "to-be" analysis of the relevant systems involved in the business process is essential. The following may augment the model construction process: A phase where the process is tested on a sample of diverse integration projects, and some mechanism of evaluating success criteria of the application of the resultant models in the diverse projects.

On the suitability of the approach used to validate the proposed EAI process model and/or aspects of the approach that needed improvement, it was agreed that involving experts well versed in the practice of information systems development to check for conformance to methods requirements and industry best practices but only if you get the right experts.

The improvements identified in relation to suitability of the approach include: more one-to-one seminar-like presentations that often bring better results; a full validation using a live project including feedback via "lessons-learnt"; subject to practical time and budgetary constraints, the model could be validated through actual utilization in a few (preferably, significantly different) integration projects.

On whether they would use the proposed model for their integration projects, the experts affirmed this model can be used for any integration project, the key reasons being: it appears credible and as an improvement of the existing models, which are themselves well established and tested; it appears comprehensive enough and handles most of the likely emergent issues; the flow is good. The deliverables are well described but should try to bring out more description. The deliverables should be identified and the IDs used to link it back and forward to other deliverables.

Furthermore, the following aspects of the model were identified as needing improvement: the model should not be rigid so as to allow one to change according to circumstances; the model should have short descriptive tasks; the model requires enhancements, with a view of targeting practitioners; the description of the model could be enhanced by providing the practitioners with well annotated use cases; although it has been successfully applied in the KRA project, a step by step illustration of the method use a simpler scenario would be useful.

The overall rating based on the requirements in Table 1 on a scale of $1-10$ is shown in Table 2 .

Table 2: Process Model Expert Rating

\begin{tabular}{|l|l|}
\hline ID & Mean \\
\hline R01 & 7.6 \\
\hline R02 & 8.4 \\
\hline R03 & 8.0 \\
\hline R04 & 8.2 \\
\hline R05 & 8.4 \\
\hline R06 & 8.0 \\
\hline R07 & 8.3 \\
\hline R08 & 7.6 \\
\hline R09 & 7.4 \\
\hline
\end{tabular}

\section{\begin{tabular}{|l|l|}
\hline Mean & $\mathbf{8 . 0}$ \\
\hline
\end{tabular} \\ 4.2.2 Business Scenario Validation}

A study was conducted in the selected study area ("Integration Domain") using the proposed model with the aim of demonstrating how the various steps in the recommended process model can be achieved. The customs clearance processes in the study and the templates recommended in Appendix 1 were used for the purpose. This process of validation involved applying the proposed model and templates, getting result from the application area and evaluating those results. The results are summarized in Table 3 below. 
Table 3: Summary of Business Scenario Results

\begin{tabular}{|c|c|c|c|}
\hline Step & Step & Activity & Results/Deliverable Obtained \\
\hline Step 1 & $\begin{array}{l}\text { Business } \\
\text { Area } \\
\text { Analysis }\end{array}$ & $\begin{array}{l}\text { Organizational Analysis; } \\
\text { Stakeholder Analysis; } \\
\text { Application Analysis }\end{array}$ & $\begin{array}{l}\text { Description of participating organizations: the Customs Services } \\
\text { Department, the National Port, and the Maritime Authority; } \\
\text { Analysis of various stakeholders: Shipping Agents, Clearing Agents, } \\
\text { Banks, Consolidators, Airlines, Ground Handlers, and the National } \\
\text { Shipping Agents Association; } \\
\text { Analysis of the key applications: Common Cash Receipting Systems, } \\
\text { Simba System, Port Water Front Operating System }\end{array}$ \\
\hline Step 2 & $\begin{array}{l}\text { Business } \\
\text { Process } \\
\text { Analysis }\end{array}$ & $\begin{array}{l}\text { Identification of Business } \\
\text { Processes; Identification of } \\
\text { Message Flows; } \\
\text { Construction of Current } \\
\text { Process Flows (AS-IS); } \\
\text { Creation of Message } \\
\text { Descriptions; Creation of } \\
\text { Process Descriptions and } \\
\text { Identification of Weaknesses } \\
\text { in Current Processes }\end{array}$ & $\begin{array}{l}\text { Analysis of the following current business processes with detailed } \\
\text { documentation about message flows using process diagrams, process } \\
\text { descriptions, message descriptions, and identification of weaknesses in } \\
\text { the processes : } \\
\text { - Sea Manifest Declaration } \\
\text { - Air Manifest Declaration } \\
\text { - Sea Manifest Amendment } \\
\text { - Air Manifest Amendment } \\
\text { - Sea Supplementary Manifest } \\
\text { - Air Supplementary Manifest } \\
\text { - Sea Customs Import Entry Declaration } \\
\text { - Air Customs Import Entry Declaration }\end{array}$ \\
\hline Step 3 & $\begin{array}{l}\text { Business } \\
\text { Process } \\
\text { Redesign }\end{array}$ & $\begin{array}{l}\text { Functional Requirements } \\
\text { Analysis; Data Requirements } \\
\text { Analysis; Construct } \\
\text { Proposed Process Flow (TO- } \\
\text { BE); Non-Functional } \\
\text { Requirements Analysis; }\end{array}$ & $\begin{array}{l}\text { We recommended changes in each of the } 8 \text { business processes in the } \\
\text { integration domain, with the rationale given. These changes were } \\
\text { influenced by the challenges and weaknesses identified, and the need to } \\
\text { remove business process bottlenecks by removing manual documents } \\
\text { and implementing application-to-application data exchange wherever } \\
\text { possible. Proposed process flows were constructed using process } \\
\text { diagrams }\end{array}$ \\
\hline Step 4 & Design & $\begin{array}{l}\text { Message Design; Select } \\
\text { Integration Solution }\end{array}$ & $\begin{array}{l}\text { We created structure for a message called Vessel Schedule that details a } \\
\text { vessel call or voyage with details such as voyage no. booking no. ETA, } \\
\text { port of origin, port of destination, call sign, nationality, gross tonnage }\end{array}$ \\
\hline Step 5 & Build & Coding; Testing & $\begin{array}{l}\text { Using XML we coded and tested a message schema for Vessel } \\
\text { Schedule }\end{array}$ \\
\hline
\end{tabular}

\section{CONCLUSIONS}

Although there are many methodologies for Enterprise Application Integration in existence, it is rare to find one that suits all aspects of a given project. However, method tailoring techniques exist to construct a method from existing ones to suit a given situation. This could either be by gathering useful parts of existing methods to build a new one or extend an existing one by filling the missing gaps. This research was motivated by the need to develop a structured way of addressing the challenges of EAI that have been experienced at the Customs Department in Kenya after it was realized that the existing system development methodologies were not adequately addressing application integration projects in the Department.

This paper proposed a process model for analysis and design of Enterprise Application Integration projects in a Customs Department. The process model described a set of activities that should be carried out during analysis and design and prescribes key deliverables for each activity. The model was constructed using situational method engineering techniques and validated through expert reviews. The process model was applied to the Department to demonstrate applicability and to facilitate validation. The results obtained demonstrate the model appears credible and comprehensive enough to handle most of the likely emergent issues. Suggestions were made on how to improve the model.
Selection of the actual technologies to use for systems integration is still a challenge. Although this paper proposes a checklist of factors to consider, there is still need for more work in this area.

This research demonstrated use of the process model in a real business environment, but is does not provide metrics to measure the subsequent success or otherwise of the integration initiative. This is an area that is important and recommended for further work. This may cover factors such as ease of maintenance of resulting solution (given this is influenced by documentation created in the model), ease of tracking and maintaining project documentation etc. It may also be critical to be able to compare the views of process users who may have used other approaches.

A number of limitations were noted. First, assembly method techniques are based on the concept of a "method base". This is a repository of parts of a method that perform specific tasks. To effectively use and build a method base, many relevant methods are required. For the case of this research, only three methods were used to create a method base.

As noted by one of the expert reviewers, review of methods is a very important undertaking that should involve many experts. These experts should have an obvious interest in the 
problem domain. Questionnaires are seldom enough. More detailed and technical deliberations, such as seminars and conferences proper critique is guaranteed, are advisable.

In process model or method development, it is important to have a way of measuring applicability or otherwise of the resultant product via measurable metrics. In this research, there was no activity to test how successful an integration initiative using the proposed model would be.

\section{ACKNOWLEDGMENTS}

We would like to thank the Custom Department of the Kenya Revenue Authority for allowing us to use their business processes. We also thank the five experts from different countries who participated in the validation process.

\section{REFERENCES}

[1] Bosch, M.V. (2010). A Selection-Method for Enterprise Application Integration Solutions. Utrecht: Utrecht University.

[2] Brinkkemper, S. (1996). Method Engineering: Engineering of Information Systems Development Methods and Tools. Information and Software Technology, 38, 275-280.

[3] Chen, Y. and Wong, A. (2004). E-Business: Factors of EAI Adoption in an Australian Electricity Company. Proceeding of the 4th International Conference on Electronic Business (ICEB2004) / Beijing, pp 1289 1294.

[4] EAI Industry Consortium (2004). Total Business Integration Methodology.

[5] Erasala, N., Yen, D.C., Rajkumar, T.M. (2003). Enterprise Application Integration in the Electronic Commerce World. Computer Standards \& Interfaces, 25, 69-82. Elsevier Science.

[6] Irani, Z., Themistocleous, M., \& Love, P. E. (2003). The impact of Enterprise Application Integration on Information System Lifecycles. Information \& Management, 177-187.

[7] Kamal, M.M. and Themistocleous, M.(2009). Investigating EAI Adoption in the Local Government Authorities: A Case of Mapping the Influential Factors on the Adoption Lifecycle Phases. Transforming Government: People, Process and Policy, Vol. 3 Iss: 2, pp. $190-212$.

[8] Linthincum, D.S. (2000). Enterprise Application Integration. London: Addison Wesley.
[9] Losavio, F., Ortega, D., Perez, M. (2005). Comparison of EAI Frameworks. Journal of Object Technology, Vol 4, No. 4., pp. 93-114

[10] Mantzana, V. and Themistocleous, M. (2006). Benefits and Barriers Related to EAI Adoption: The Case of a Healthcare Organization. ECIS Proceedings. Paper 183

[11] Oba, M., Komoda, N. (2001). Multiple Type Workflow Model for Enterprise Application Integration. Proceedings of the 34th Hawaii International Conference on System Science, pp $1-8$.

[12] Ralyté, J., \& Rolland, C. (2001). An Assembly Process Model for Method Engineering. CAiSE’01 Proceedings of the 13th International Conference on Advanced Information Systems Engineering, 267-283. London: Springer-Verlag.

[13] Rolland, C. (1998). A Comprehensive View of Process Engineering. CAiSE'98 Proceedings of the 10th International Conference on Advanced Information Systems Engineering, 1-24, CREWS Report Series 98. Pisa, Italy: Springe.

[14] Scacchi, W. (2001). Process Models in Software Engineering. In M. J. (ed.), Encyclopedia of Software Engineering ( 2 ed.). New York: John Wiley and Sons, Inc.

[15] Sharif, A.M., Irani, Z., and Love, P.E.D., (2005). Integrating ERP using EAI: a Model for Post Hoc Evaluation. European Journal of Information Systems Special Issue, Vol. 14, Issue 2, pp 162 - 174.

[16] Surugiu, I. (2012). Integration of Information Technologies in Enterprise Application Development. Database Systems Journal Vol. III, No. 1, pp 21 - 31.

[17] TechTarget. (2009). EAI and Web Services First Steps. Retrieved June 15, 2012, from BitPipe Research Guide: http://www.bitpipe.com

[18] Themistocleous, M., \& Irani, Z. (2006). Towards a Methodology for the Development of Integrated IT Infrastructures. Proceedings of the 39th Hawaii International Conference on System Sciences. Hawaii.

[19] Weerd, I. V. (2005). WEM: A Design Method for CMSbased Web Implementations. Utrecht, Netherlands: University of Utrecht.

[20] Xin, J. (2009). Research on the Model of Enterprise Application Integration with Web Services. Proceedings of the 3rd WSEAS International Conference on Computer Engineering and Applications (CEA'09), pp $105-109$. 
Appendix 1: Process Model Templates

\section{A1.0 Introduction}

A number of products are recommended for the proposed process model. This appendix presents the templates that may be used for the products.

\section{A1.1 Organization Analysis Template}

PROJECT NAME:

\section{GENERAL DETAILS}

\begin{tabular}{|l|l|}
\hline Organization & $\{$ Name of the organization $\}$ \\
\hline Business Area & $\{$ General statement of what the organization does $\}$ \\
\hline $\begin{array}{l}\text { Role /Interest in the Integration } \\
\text { Project }\end{array}$ & $\begin{array}{l}\text { \{Why is the organization interested in the integration project? What role is it } \\
\text { expected to play? }\end{array}$ \\
\hline Perceived Automation Level & \{Rate High, Medium, or Low. Insert also relevant remarks $\}$ \\
\hline
\end{tabular}

\section{ANALYSIS OF PARTICIPATING ORGANIZATIONS}

\{Below, list and briefly describe all systems likely to be affected by the integration initiative\}

\begin{tabular}{|c|c|c|}
\multicolumn{2}{|c|}{ SYSTEMS/APPLICATIONS } \\
\hline System & \multicolumn{1}{|c|}{ Description } & \multicolumn{1}{c|}{ Likely Effects } \\
\hline$\{$ Name $\}$ & \{What the system does $\}$ & $\begin{array}{l}\{\text { How system is likely to be affected by the integration } \\
\text { project }\}\end{array}$
\end{tabular}

\{Below, list and briefly describe all messages currently exchanged and likely to be affected by the integration initiative

\section{KEY MESSAGES/DOCUMENTS}

\begin{tabular}{|l|l|l|l|}
\hline \multicolumn{1}{|c|}{ KEY MESSAGES/DOCUMENTS } & \multicolumn{1}{c|}{$\begin{array}{l}\text { Responsibility } \\
\text { (Send/Receive) }\end{array}$} & \multicolumn{1}{c|}{ To/From } \\
\hline $\begin{array}{l}\text { ID unique ref } \\
\text { number assigned to } \\
\text { identify a message }\}\end{array}$ & Message/Document & $\{$ Name of document/message $\}$ & $\begin{array}{l}\{\text { Stakeholder on the other } \\
\text { end of send/receive }\}\}\end{array}$ \\
\hline
\end{tabular}

Stakeholder Analysis Template

PROJECT NAME:

\begin{tabular}{|c|c|c|c|c|}
\hline \multicolumn{5}{|c|}{ STAKEHOLDER ANALYSIS } \\
\hline Stakeholder & Stake in the Project & Potential impact & Expected Role & Important to Know \\
\hline $\begin{array}{l}\{\text { Name of } \\
\text { stakeholder\} }\end{array}$ & $\begin{array}{l}\text { \{What interest does } \\
\text { the stakeholder have in } \\
\text { the project? How will } \\
\text { they be affected?\} }\end{array}$ & $\begin{array}{l}\text { \{Rated High, Medium, } \\
\text { Low }\}\end{array}$ & $\begin{array}{l}\text { \{What does the } \\
\text { Project expect the } \\
\text { Stakeholder to } \\
\text { provide?\} }\end{array}$ & $\begin{array}{l}\text { \{Perceived attitudes } \\
\text { and/or risks\} }\end{array}$ \\
\hline
\end{tabular}


A1.2 Process Analysis Template

\begin{tabular}{|c|c|}
\hline \multicolumn{2}{|c|}{ PROJECT NAME: } \\
\hline Process & $\{$ Name of process $\}$ \\
\hline Purpose & \{What does the process achieve\} \\
\hline Owner & $\begin{array}{l}\text { \{Person who has the ultimate responsibility for the performance of and has the power to authorize } \\
\text { necessary changes\} }\end{array}$ \\
\hline Description & \{Step-wise description of the flow of key activities/tasks\} \\
\hline Inputs & \{Messages or documents that flow into the process\} \\
\hline Outputs & \{Messages or documents that flow out of the process\} \\
\hline Weaknesses & \{Problems that are important to note and that integration should probably address $\}$ \\
\hline Important facts & $\{$ Important to know $\}$ \\
\hline
\end{tabular}

\section{A1.3 Message Description Template}

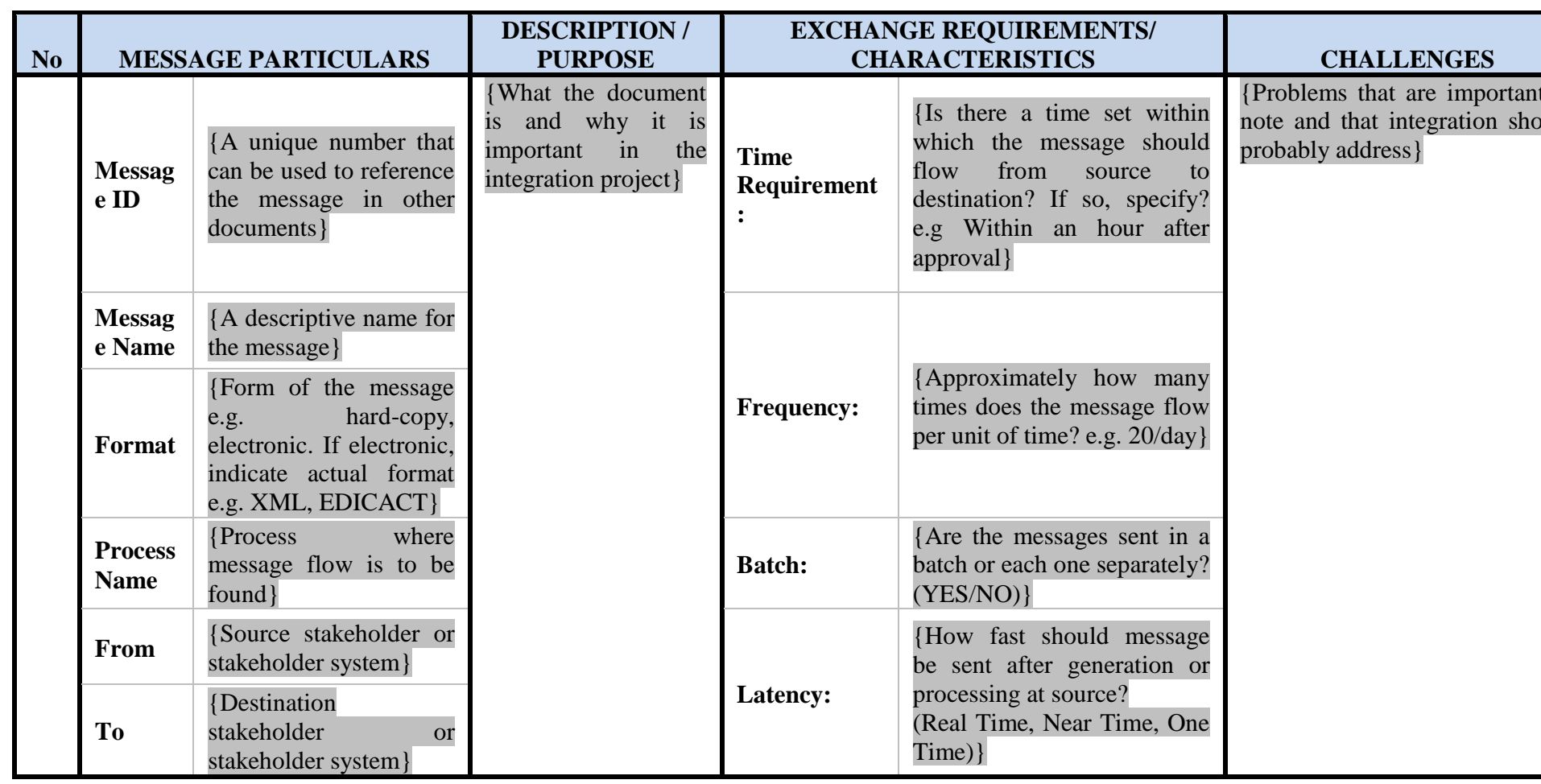




\section{A1.4 Message Structure Template}

Table 1: Message Structure Template

MESSAGE: $\{$ Name of Message $\} \quad$ ID: $\{$ Message ID - Unique identifier for message $\}$ DESCRIPTION: \{Short description of message\}

COMPOSITE DATA ELEMENT (CDE) CONTENT \{This section defines data structures that form the message.\}

\begin{tabular}{|c|c|c|c|c|}
\hline CDE Name & Description & \multicolumn{2}{|c|}{ Parent Data Structure } & Cardinality \\
\hline $\begin{array}{l}\text { \{Name of data } \\
\text { Structure\} }\end{array}$ & \{Short description of data structure\} & \multicolumn{2}{|c|}{$\begin{array}{l}\text { \{The data structure that } \\
\text { contain this data structure\} }\end{array}$} & $\begin{array}{l}\text { \{How many possible } \\
\text { occurrences of this data } \\
\text { structure can be expected in } \\
\text { the parent? }\end{array}$ \\
\hline .. &.. & \multicolumn{2}{|l|}{..} &. \\
\hline \multicolumn{5}{|c|}{ DATA ELEMENT (DE) CONTENT \{This section defines data elements that form the message.\} } \\
\hline Name & Description & $\begin{array}{l}\text { Parent Data } \\
\text { Structure }\end{array}$ & Optionality & Format \\
\hline $\begin{array}{l}\text { \{Name of data } \\
\text { element\} }\end{array}$ & \{Short description of data element $\}$ & $\begin{array}{l}\text { \{The data } \\
\text { structure that } \\
\text { contain this data } \\
\text { element }\}\end{array}$ & $\begin{array}{l}\text { \{O-Optional } \\
\text { M-Mandatory } \\
\text { C- } \\
\text { Conditional }\}\end{array}$ & $\begin{array}{l}\text { \{Data type and } \\
\text { appearance of the data\} }\end{array}$ \\
\hline .. & .. & .. & .. & .. \\
\hline .. & .. & .. & .. & .. \\
\hline
\end{tabular}


Appendix 2 Checklist for Selection of an EAI Technology

\begin{tabular}{|c|c|c|c|c|}
\hline FACTOR & DESCRIPTION & OUTCOME & TECHNOLOGIES & $\begin{array}{l}\text { RATIONALE FOR } \\
\text { RECOMMENDATION }\end{array}$ \\
\hline \multirow[t]{2}{*}{$\begin{array}{l}\text { Type of } \\
\text { transaction }^{1}\end{array}$} & \multirow[t]{2}{*}{$\begin{array}{l}\text { How long does the } \\
\text { application at the } \\
\text { message destination take } \\
\text { to process the request? }\end{array}$} & $\begin{array}{l}\text { Long running } \\
\text { transactions }\end{array}$ & Message queues & $\begin{array}{l}\text { Using message queues releases the } \\
\text { application to proceed with other tasks } \\
\text { and can get any necessary feedback later } \\
\text { could take quite a while, but we don't } \\
\text { need to wait for it }\end{array}$ \\
\hline & & $\begin{array}{l}\text { Short running } \\
\text { transactions }\end{array}$ & $\begin{array}{l}\text { Request/Response such as } \\
\text { RPC, Web Services }\end{array}$ & $\begin{array}{l}\text { Because of the short processing time, a } \\
\text { request/response implementations that } \\
\text { are also easier to implement are better. }{ }^{1}\end{array}$ \\
\hline \multirow[t]{3}{*}{ Data Latency $^{2}$} & \multirow[t]{3}{*}{$\begin{array}{l}\text { How fast should } \\
\text { message be delivered to } \\
\text { destination after } \\
\text { generation/processing at } \\
\text { source? }\end{array}$} & Real Time & $\begin{array}{l}\text { Synchronous } \\
\text { Request/Response such as } \\
\text { RPC-based, Web Services } \\
\text { OR synchronous MOM } \\
\text { such as (synchronous) } \\
\text { message queues }\end{array}$ & $\begin{array}{l}\text { It may be important to sometimes block } \\
\text { current process until a success response is } \\
\text { obtained from the destination. }\end{array}$ \\
\hline & & Near Time & $\begin{array}{l}\text { Asynchronous MOM such } \\
\text { as (asynchronous) message } \\
\text { queues. A Web Service } \\
\text { may also be implemented } \\
\text { at the server end and client } \\
\text { may also be implemented } \\
\text { at the receiving end to } \\
\text { send requests at scheduled. }\end{array}$ & $\begin{array}{l}\text { Near time means message can be } \\
\text { delivered at scheduled times or scheduled } \\
\text { intervals. So the provider and recipient } \\
\text { need not be both present at the same } \\
\text { time. }\end{array}$ \\
\hline & & One Time & Any of the technologies & $\begin{array}{l}\text { One time means the message is only } \\
\text { expected to be received once ever. The } \\
\text { technology choice here would therefore } \\
\text { be governed by other factors }\end{array}$ \\
\hline \multirow{2}{*}{$\begin{array}{l}\text { Number of } \\
\text { current and } \\
\text { potential } \\
\text { message } \\
\text { consumers }^{3}\end{array}$} & \multirow[t]{2}{*}{$\begin{array}{l}\text { How many consumers } \\
\text { are expected of each } \\
\text { instance of a message? }\end{array}$} & Zero-to-Many & $\begin{array}{l}\text { Asynchronous MOM } \\
\text { based on the Publish- } \\
\text { subscribe model. }\end{array}$ & $\begin{array}{l}\text { This allows the provider to send data } \\
\text { when it is available and the recipients to } \\
\text { receive same at their own time. }\end{array}$ \\
\hline & & One only & $\begin{array}{l}\text { Point to point MOM such } \\
\text { as message queues OR } \\
\text { Request/Response such as } \\
\text { RPC, Web Services. }\end{array}$ & $\begin{array}{l}\text { Since only one recipient is expected, it is } \\
\text { cheaper to have a point-to-point } \\
\text { implementation. }\end{array}$ \\
\hline \multirow[t]{2}{*}{$\begin{array}{l}\text { Scalability } \\
\text { Expectations }^{3}\end{array}$} & \multirow{2}{*}{$\begin{array}{l}\text { Are appreciable growths } \\
\text { in number and size of } \\
\text { messages exchanged as } \\
\text { well as message } \\
\text { consumers expected over } \\
\text { time? }\end{array}$} & $\begin{array}{l}\text { High growth } \\
\text { expectations }\end{array}$ & $\begin{array}{l}\text { Message queue } \\
\text { publish/subscribe models }\end{array}$ & $\begin{array}{l}\text { A message queue gives you the ability to } \\
\text { distribute work across physical nodes and } \\
\text { provide load balancing capabilities. }\end{array}$ \\
\hline & & $\begin{array}{l}\text { No growth } \\
\text { expectations }\end{array}$ & $\begin{array}{l}\text { Use other technologies as } \\
\text { determined by other } \\
\text { factors. }\end{array}$ & \\
\hline $\begin{array}{l}\text { Data source } \\
\text { Locations }^{2}\end{array}$ & $\begin{array}{l}\text { How far apart are data } \\
\text { sources? Are they in } \\
\text { different networks? }\end{array}$ & Same network & $\begin{array}{l}\text { Data-Level techniques are } \\
\text { possible }\end{array}$ & $\begin{array}{l}\text { Data-Level techniques are possible but } \\
\text { their use should depend on other factors }\end{array}$ \\
\hline $\operatorname{Cost}^{4}$ & $\begin{array}{l}\text { What are the cost } \\
\text { constrints }\end{array}$ & $\begin{array}{l}\text { Specific cost } \\
\text { constraints }\end{array}$ & $\begin{array}{l}\text { Depends on what is } \\
\text { available to spend on the } \\
\text { integration. }\end{array}$ & $\begin{array}{l}\text { Method-Level implementations such as } \\
\text { application servers and transaction } \\
\text { processing monitors are usually very } \\
\text { expensive, so may not be feasible when } \\
\text { there is inadequate funding. }\end{array}$ \\
\hline $\begin{array}{l}\text { Message } \\
\text { format } \\
\text { constraints }\end{array}$ & $\begin{array}{l}\text { Are there any constraints } \\
\text { with respect to the data } \\
\text { formats that can be used } \\
\text { for the exchange? }\end{array}$ & $\begin{array}{l}\text { There are } \\
\text { constraints }\end{array}$ & $\begin{array}{l}\text { Depends on the exact } \\
\text { constraints }\end{array}$ & $\begin{array}{l}\text { If message format conversion is required } \\
\text { from source to destination, it may be } \\
\text { necessary to build an additional layer for } \\
\text { this. Alternatively, tools for same may } \\
\text { need to be acquired. }\end{array}$ \\
\hline
\end{tabular}

\footnotetext{
${ }^{1}$ Ref: (TechTarget, 2009)

${ }^{2}$ Ref: (Linthincum, 2000)

${ }^{3}$ Ref: (Snyder, Davies, \& Bosanac, 2009)

${ }^{4}$ Questionnaire
} 


\begin{tabular}{|c|c|c|c|c|}
\hline FACTOR & DESCRIPTION & OUTCOME & TECHNOLOGIES & $\begin{array}{c}\text { RATIONALE FOR } \\
\text { RECOMMENDATION }\end{array}$ \\
\hline $\begin{array}{l}\text { Operating } \\
\text { environments } \\
\text { of both the } \\
\text { sending and } \\
\text { receiving } \\
\text { applications }\end{array}$ & $\begin{array}{l}\text { What are the operating } \\
\text { systems of both sending } \\
\text { and receiving } \\
\text { applications? }\end{array}$ & $\begin{array}{l}\text { Operating } \\
\text { systems }\end{array}$ & $\begin{array}{l}\text { Depends on operating } \\
\text { environments. }\end{array}$ & $\begin{array}{l}\text { Some solutions are operating } \\
\text { environment-independent e.g. web } \\
\text { services because they are open standards. } \\
\text { Others are only feasible in certain } \\
\text { environments e.g. COM, DCOM are best } \\
\text { suited for Microsoft platforms (although } \\
\text { it is claimed they are cross-platform, it is } \\
\text { difficult to achieve the cross-platform } \\
\text { integration) }{ }^{2}\end{array}$ \\
\hline $\begin{array}{l}\text { Technology } \\
\text { constraints by } \\
\text { receiving } \\
\text { application or } \\
\text { organization }^{4} \\
\end{array}$ & $\begin{array}{l}\text { Do either the sending or } \\
\text { receiving systems have } \\
\text { any technologies they } \\
\text { may not be able to } \\
\text { support? }\end{array}$ & $\begin{array}{l}\text { There are } \\
\text { unsupportable } \\
\text { technologies }\end{array}$ & $\begin{array}{l}\text { The unsupportable } \\
\text { technologies cannot be } \\
\text { considered }\end{array}$ & $\begin{array}{l}\text { If an organization places constraints, the } \\
\text { choice of technology would have to } \\
\text { conform. }\end{array}$ \\
\hline $\begin{array}{l}\text { Features of the } \\
\text { Applications }{ }^{1}\end{array}$ & $\begin{array}{l}\text { Does the application } \\
\text { have any built-in } \\
\text { standard adapters meant } \\
\text { for integration? }\end{array}$ & $\begin{array}{l}\text { There are in- } \\
\text { built standard } \\
\text { interfaces }\end{array}$ & $\begin{array}{l}\text { If the exposed adapters are } \\
\text { useful, it is recommended } \\
\text { to make use of them }\end{array}$ & $\begin{array}{l}\text { Packaged applications from different } \\
\text { vendors sometimes come with standard } \\
\text { adapters that can be used. }\end{array}$ \\
\hline \multirow[t]{2}{*}{$\begin{array}{l}\text { Order of } \\
\text { delivery of } \\
\text { messages }^{3}\end{array}$} & \multirow[t]{2}{*}{$\begin{array}{l}\text { Are there messages } \\
\text { related to the current one } \\
\text { that MUST strictly be } \\
\text { delivered either before or } \\
\text { after the current one is } \\
\text { delivered? }\end{array}$} & $\begin{array}{l}\text { Delivery order } \\
\text { important }\end{array}$ & $\begin{array}{l}\text { Message queue based } \\
\text { technologies }\end{array}$ & $\begin{array}{l}\text { Message queue based technologies have } \\
\text { inbuilt capabilities to deliver message in } \\
\text { a specified order without having to re- } \\
\text { implement same. However, it is possible } \\
\text { to the ordering to be enforced via } \\
\text { necessary logic in both the sending } \\
\text { applications although where changing } \\
\text { these is not an option, message queue } \\
\text { may the best option. }\end{array}$ \\
\hline & & $\begin{array}{l}\text { Delivery order } \\
\text { NOT important }\end{array}$ & $\begin{array}{l}\text { Use other technologies as } \\
\text { determined by other } \\
\text { factors. }\end{array}$ & \\
\hline \multirow[t]{2}{*}{$\begin{array}{l}\text { Importance of } \\
\text { message? }^{3}\end{array}$} & \multirow{2}{*}{$\begin{array}{l}\text { How important is the } \\
\text { message? MUST it be } \\
\text { delivered? Will there be } \\
\text { dire business } \\
\text { consequences if it is not } \\
\text { delivered? }\end{array}$} & $\begin{array}{l}\text { Message MUST } \\
\text { be delivered }\end{array}$ & $\begin{array}{l}\text { Message queue based } \\
\text { technologies }\end{array}$ & $\begin{array}{l}\text { Message queue based technologies } \\
\text { guarantee delivery of the message. }\end{array}$ \\
\hline & & $\begin{array}{l}\text { No problem } \\
\text { even if message } \\
\text { is NOT } \\
\text { delivered }\end{array}$ & $\begin{array}{l}\text { Any technologies as } \\
\text { determined by other } \\
\text { factors. }\end{array}$ & \\
\hline \multirow[t]{2}{*}{$\begin{array}{l}\text { How crucial is } \\
\text { data } \\
\text { consistency } \\
\text { among } \\
\text { different data } \\
\text { sources for } \\
\text { this message? }\end{array}$} & \multirow[t]{2}{*}{$\begin{array}{l}\text { Must the same data sets } \\
\text { be exactly the same } \\
\text { among different } \\
\text { applications sharing data } \\
\text { at the same time? }\end{array}$} & Very Critical & $\begin{array}{l}\text { Transaction } \\
\text { monitor/application server- } \\
\text { based solutions are the } \\
\text { best. However, it is also } \\
\text { possible to enforce this } \\
\text { consistency by other ways } \\
\text { such as synchronous } \\
\text { technologies, but this has } \\
\text { its own problems. }\end{array}$ & $\begin{array}{l}\text { Transactional middleware controls } \\
\text { transactions from their beginning to their } \\
\text { end, from the client to the resource } \\
\text { server, and then back and always leaves } \\
\text { the system in a stable state i.e. never } \\
\text { incomplete and either succeeds or fails as } \\
\text { a whole. Therefore it is not possible to } \\
\text { have some bits of the transactions that } \\
\text { succeeded and others that did not. }\end{array}$ \\
\hline & & Not critical & $\begin{array}{l}\text { Any technologies as } \\
\text { determined by other } \\
\text { factors. }\end{array}$ & \\
\hline \multirow[t]{2}{*}{$\begin{array}{l}\text { Does the } \\
\text { message } \\
\text { expire? }^{4}\end{array}$} & \multirow[t]{2}{*}{$\begin{array}{l}\text { Is there a timeline within } \\
\text { which the message } \\
\text { should not be delivered } \\
\text { if not already consumed? }\end{array}$} & $\begin{array}{l}\text { Message } \\
\text { expires }\end{array}$ & $\begin{array}{l}\text { Message queue based } \\
\text { technologies }\end{array}$ & $\begin{array}{l}\text { Message queue based technologies can be } \\
\text { configured NOT to deliver a message if } \\
\text { same is not delivered in a given time } \\
\text { period. }\end{array}$ \\
\hline & & $\begin{array}{l}\text { Message does } \\
\text { NOT expire }\end{array}$ & $\begin{array}{l}\text { Any technologies as } \\
\text { determined by other } \\
\text { factors. }\end{array}$ & \\
\hline
\end{tabular}

